\title{
Bronze Age Representations of Aegean Bull-Leaping
}

\author{
JOHN G. YOUNGER
}

\begin{abstract}
There were three main systems for depicting Aegean bull-leaping in the Late Bronze Age. Type I was described by Evans, Type II by Mrs. Sakellariou, while Type III is here presented for the first time. Though Types I and III seem to reflect several aesthetic considerations, Type II may illustrate the sport more accurately. All three types include several examples that come with known proveniences and from dated contexts. These examples suggest that Type I was a Cretan schema with a floruit in LM I, Type III a Mycenaean schema with a floruit in $\mathrm{LH}$ IIIB, and Type II a Cretan and Mycenaean schema dating primarily before the beginning of LB IIIB. If Type II depicts bull-leaping accurately then the sport may not have been practiced after LB IIIA:2.
\end{abstract}

\section{INTRODUCTION*}

Minoan and Mycenaean bull-leaping ${ }^{1}$ has been a popular subject of discussion and speculation since I 884 when Heinrich Schliemann found at Tiryns a fresco depicting the sport (III.I below). Later, the excavations at Knossos produced many frescoes and sealings representing other aspects of bull-leaping, and these provoked wider interest.

In rgog A. Reichel published a catalogue of the representations known at the time and he attempted some general conclusions. ${ }^{2}$ But an elucidation of the maneuvers in the sport had to wait until

\footnotetext{
* In addition to the standard abbreviations the following are used:

Betts - J. Betts, "New Light on Minoan Bureaucracy," Kadmos 6 (1967) 15-40.

CM-A. Sakellariou, Les Cachets minoens.

CMS - Corpus der minosichen und mykenischen Siegel.

CS - V.E.G. Kenna, Cretan Seals.

KFA - M. Cameron and S. Hood, The Knossos Fresco Atlas.

KSPI - M.A.V. Gill, "The Knossos Sealings; Provenance and Identification," BSA 60 (I965) 58-98.

Levi $A T$ - D. Levi, "Le Cretule di Haghia Triada," AsAtene 8-9 (I925-1926) 7I-I 56.

Levi $K Z-D$. Levi, "Le Cretule di Zakro," AsAtene 8-9) (1925-1926) I 57-201.

PM -A. Evans, The Palace of Minos.

Sakellariou $-C M 85-89$.

The author is grateful for the use of several photographs: to Dr. I. Pini Redactor of $C M S$ for figs. I, 2, 15, 17, and 24; to the Trustees of the British Museum for fig. 3; to the Ashmolean Museum for figs. 4, 5, 9-I2, and 23; the rest are by the author.
}

PLATES $20-22$

Sir Arthur Evans in I921 and I930 treated the subject of bull-leaping in two admirable studies. ${ }^{3}$

In his later essay Evans published several representations of bull-leaping found on sealstones and in wall and relief frescoes. He also presented a drawing in good Minoan style by Theodore Fyfe (PM III fig. 156, our ill. I), a lucid diagram of the various positions a leaper might assume. Evans's discussion of the sport is informative and entertaining with enlightening digressions on rodeos in the American West, on Iberian bull sports, and on the taurokathapsiai of Roman Thessaly. His reconstruction of the Minoan feat (Evans's Schema, below) rests, however, almost exclusively on its depiction in the bronze group (I.6 below) from near Rethymnon now in the British Museum (pl. 20, fig. 3). ${ }^{4}$ He appears to ignore the ample evidence of different methods of depicting the leap as presented in other media, the most noteworthy representation being the Knossos Taureador fresco (II.I5 below).

Mrs. A. Sakellariou in 1958 again catalogued the known representations of bull-leaping and bullgrappling. ${ }^{5}$ She divided the poses of the bull-leaper into two main groups; a third includes only representations of bull-grappling. Her first group lists depictions which she thought would fit Evans's sys-

None of the photographs is to scale. Appreciation is also due to Abby Watrous for the illustration of the Diving Leaper Schema (ill. 2).

1 Bull-leaping, the sport, is here considered apart from bullgrappling, which may be defined as the securing of wild or angered bulls; the representations of this activity should form a separate study. Examples of bull-grappling may be seen on Vapheio Cup B, and on many sealstones and sealings. The legends of Theseus and Herakles wrestling the Knossian Bull and of Theseus and Androgeos son of Minos capturing the Marathonian Bull may have sprung from such bull-grappling contexts.

2 "Die Stierspiele in der kretisch-mykenischen Cultur," AthMit 34 (1909) 85-99.

3 "On a Minoan Bronze Group of a Galloping Bull and Acrobatic Figure from Crete," JHS 4 I (I92I) 247-59; PM III 203-32.

" Ibid., "Minoan Bronze" figs. I and 2, and PM III fig. I 55 .

${ }^{5}$ CM 85-89 (hereafter, Sakellariou). Of the representations cited in her Group I, a few require remarks: nos. 3 and 17 are too poorly preserved to admit a secure restoration; 6 is a forgery (infra n. 24); I I probably depicts a bull goring a would-be grappler; and 22 may have a bull-leaper (infra n. 22). 
tem. In her second group (our Type III, the Floating Leaper Schema) she saw a different, more stylized pose, whose most noteworthy representation is on a sealstone found in Gournes Tomb I (her Group II.3, our III.8), LM IIIB:I context.

Though Mrs. Sakellariou demonstrated that Evans's reconstruction is not the only system of depicting bull-leaping, his still receives such wide acceptance that major discussions of the sport have been confined to its place of performance, ${ }^{6}$ and further treatment of the maneuvers has even been thought unnecessary. Evans's Schema by now forms part of the popular image of Minoan life. The graceful swing over the bull's head, as he described it, inspired Mary Renault's vivid portrayal in The King Must Die (see below). ${ }^{8}$

A closer examination of the fifty-four representations here catalogued reveals another schema (our Type II) quite different both from Evans's reconstruction and from Mrs. Sakellariou's stylized group. In addition, three depictions cannot be assigned to any of these systems; they constitute a fourth, miscellaneous category. What follows, then, is a description of each of these four systems of representing bull-leaping, and a catalogue of the extant examples. Also discussed are the possible chronological and geographical limits to the main systems of illustrating the sport, as suggested by the representations from known and dated contexts.

In the following catalogues the examples are listed in each section according to provenience, those found in Crete given first, then those from the Mainland. Sealings impressed by a single signet are catalogued together under one number.

I. EVANS'S SCHEMA ${ }^{9}$

As noted above, Evans based his type of bullleaping on the British Museum bronze group (I.6; pl. 20, fig. 3). This sculptural group consists of a bull in flying gallop and an arched male leaper, whose head and hair are in contact with the bull's head, and whose feet touch the animal's back. The stumps of the arms are held close to the chest. Evans thought the arms were deliberately curtailed for aesthetic reasons; they may instead be broken off.

On the basis of this depiction and of a few others

\footnotetext{
${ }^{6}$ Notably, J.W. Graham, The Palaces of Crete Chapter 4.

7 A. Ward, "The Cretan Bull Sports," Antiquity 42 (I968) II 7 .

8 Part IV Chapter 4.

9 PM III 222-23, fig. I56.
}

Evans reconstructed the execution of bull-leaping as follows: the leaper approaches the bull from the front; grasping the horns, he throws himself up to execute a back flip over the bull's head, landing feet first on the animal's back; he then jumps off over the rear. Back assistants may be present to steady the leaper as he alights. ${ }^{10}$ Mary Renault presents a more vivid description; the leaper

grasped the horns, and swung up between them, going with the bull, then he soared free ... He turned in air, a curve as lovely as a bent bow's, and on the broad back his slim feet touched down together; then they sprang up again. He seemed not to leap, but to hang above the bull, like a dragonfly over the reeds, while it ran out from under him. Then he came down to earth, feet still together, and lightly touched the catcher's hands with his, like a civility ... (The King Must Die Part IV, Chap. IV)

Evans illustrated his reconstruction with an excellent diagram by Theodore Fyfe (ill. I). The main positions of the bull-leaper are there numbered: (I) approach, (2) flip, (3) landing on the back, (4) preparing to jump off the bull. In two representations (I.I and I.7) a rear assistant extends an arm up towards the leaper to assist him in his descent. There is no evidence for a front assistant in Evans's Schema.

Only seven representations definitely depict stages in Evans's Schema. All come from Crete: six sealings impressed by rings (or perhaps by amygdaloid seals) and the British Museum bronze. The sealings derive from dated contexts and cannot be later than LM Ib; the earliest may date no later than MM III. Mrs. Sakellariou places all these representations in her Group I, except for our I.2 which was probably unknown to her at the time.

Six of the seven representations, including the bronze group, depict the leaper halfway between Evans's position 2 and 3. The seventh shows him in position 3. The popularity of the leaper's pose between positions 2 and 3 may result from aesthetic considerations: the convex arch of the leaper nicely complements the concave bend of the bull's back, and the pose is well suited to the oval field of the impressing signet. Evans also suggested that the representations of bull-leaping on these sealings

\footnotetext{
10 Cf. O. Lendle, "Das kretische Stiersprungspiel," Marburger Wincklemann-Programm 1965,30-37. Note the photograph, pl. I I; also the photographs in A. Ward's The Quest for Theseus ills. I 28 and I 29 .
} 


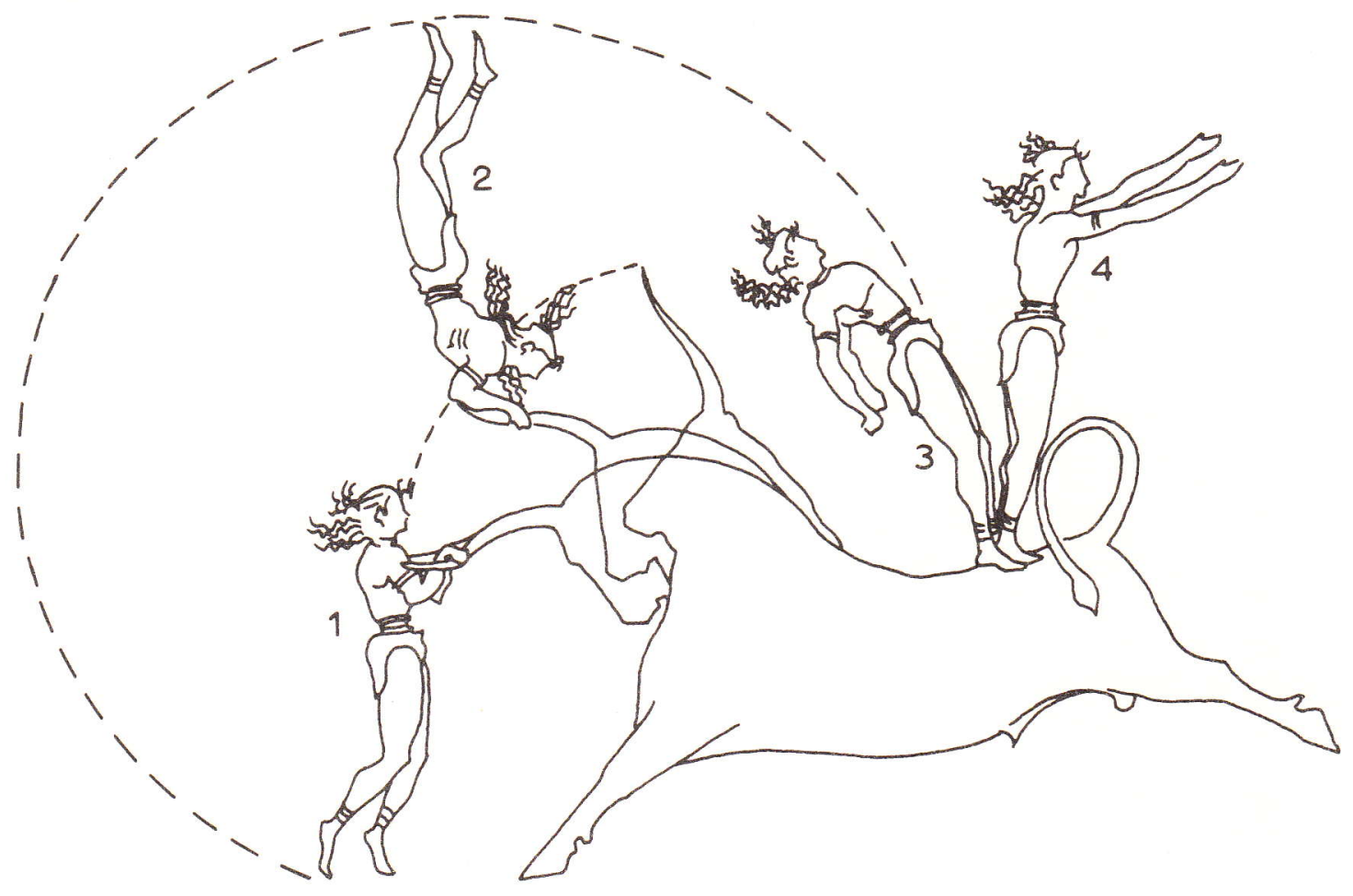

ILL. I. Evans's Schema

may have ultimately derived from such narrative frescoes as the Taureador fresco (II.I5). This and other frescoes, e.g. II.4, elaborate the sport by including subsidiary details such as plants. This elaboration seems at home on frescoes but awkward on seals.

Five more representations depict alighting leapers. These may belong either to Evans's Schema or to the succeeding type, the Diving Leaper Schema (ill. 2). These representations of alighting leapers are catalogued at the end of the latter type; see below.

\section{CATALOGUE}

A. Evans's position $2 \mathrm{I} / 2$

I.r. Sealing impressed by a ring or amygdaloid, from Knossos, the Temple Repositories. MM III? KSPI p. 70, no. L48 (HM 396); Sakellariou I.4.

Bull to left in flying gallop. Above, a leaper. Behind, an assistant.

I.2. Sealing impressed by a lentoid (?), probably from Knossos. ${ }^{11}$ LM IIIA:I?

11 Cf. Gill, "The Knossos Sealings, Some Reflections," Die kretisch-mykenische Glyptik und ihre gegenwärtigen Probleme
CMS I 517 .

Bull to left, head up. Above, a leaper.

I.3. (pl. 20, fig. I) Sealings (three) impressed by a single ring or amygdaloid. ${ }^{12}$ LM Ib.

Ayia Triada: Levi, $A T$ 144, no. I45, fig. I6ra, b (Pigorini Museum 71974); Betts fig. 7a.

Gournia: Gournia 54 (HM 102); Betts fig. rb.

Sklavokampos: EphArch 1939, p. 88, no. 3, fig. I4, pl. 4.4 (HM 6I2); Sakellariou I.I5.

Bull to left in flying gallop. Above, a leaper.

I.4. (pl. 20, fig. 2) Sealing impressed by a lentoid, from Kato Zakro. LM Ib.

Levi, $K Z$ 165, no. 123, fig. 179, pl. XV (HM 59); Sakellariou I.8.

Bull to right. Above, a leaper; below, a dado of bosses.

I.5. Sealing impressed by a ring or amygdaloid, from Kato Zakro. LM Ib.

Levi, $K Z$ I62, no. 97, fig. 173; Evans, $P M$ III 219, fig. 15 Ib; Sakellariou I.7.

Bull to right in flying gallop, head outstretched. Above, a leaper.

I.6. (pl. 20, fig. 3) Bronze miniature group (formerly in the Spencer-Churchill Collection and now in the British Museum, Ig66-3$28 /$ I), from near Rethymnon.

(Bonn-Bad Gotesbaden 1974), pp. 32-34.

12 Betts, pp. I 8 -19, attributes these sealings to a single signet. 
neuver and numbers the positions: starting from an elevated position there is (I) the descent to the bull's shoulders, (2) the back flip, and (3) the preparation for landing on the ground. Though the Diving Leaper Schema is quite different from Evans's, Mrs. Sakellariou places eight examples of this second type in her Group I; many of the fourteen other examples of Type II were published after her catalogue.

The leaper in the Diving Schema most commonly occupies position 2 or $2 \mathrm{I} / 2$. Again, this position is especially popular on sealstones and sealings probably for the same aesthetic considerations as in Evans's Schema.

Three representations II.I-3 depict a figure standing before a running bull. Evans would have made these figures leapers in his position I. Two representations of the Diving Leaper Schema (II.I5 the Taureador fresco, and II.I9) depict not only front figures but leapers as well; the standing figures are probably therefore front assistants and not leapers. These three representations (II.I-3) have therefore been included in this second schema.

All the representations belonging to the Diving Leaper Schema have known origins. Eight come from Knossos, three from various other areas in Crete; four are from the Argolid, four from the rest of the Peloponnese, one from Athens, one from Thebes, and one seal is said to be from Priene. Obviously this second schema was popular both in Crete and on the Mainland.

The ivory leapers from Knossos (II.I2) were found near the Temple Repositories; this proximity suggested to Evans a MM III date. Several sealings come from the LM Ib destruction deposits at Kato Zakro, Ayia Triada, and Sklavokampos; others, as well as some frescoes, come from Knossos, and probably date no later than LM IIIA:I. No representation from Crete can be securely dated later than this period.

On the Mainland, however, representations of this second schema span most of the Late Bronze Age. Coming from LH I-II contexts are II.2I an amygdaloid seal from Mycenae, and probably II.I I the fresco from Mycenae since it seems stylistically close to the Minoan examples. From the period

\footnotetext{
15 The Taureador fresco (II.15) has a blue background, and so do several other fresco fragments; a girl holding the horns (II.2), a leaper alighting (AL.2), and the faces of at least three other figures (KFA pl. X.6-8) may have formed part of a pendent fresco. Another fresco series with ochre background may have included a man alighting (AL.3) and part of at least one
}

just after the fall of Knossos (LH IIIA:2-IIIB:I) come II.I7 a gold ring from Asine, and II.20 a plate seal from Thebes. Three representations, II.3 and II.22 known on sealings from Pylos impressed by rings, and II.ro a lentoid from Mycenae, come from contexts dated to the close of LH IIIB.

Thus, while Evans's system may obtain only in Crete and apparently not long after the LM Ib destructions, the Diving Leaper Schema occurs on artistic representations both in Crete and on the Mainland toward the beginning of the Late Bronze Age, but exclusively on the Mainland after the fall of Knossos.

Seven of all eleven extant fresco fragments with bull-leaping scenes depict stages either of the Diving Leaper Schema or of alighting leapers. One Knossos fresco comes from the North-West Treasury (II.4). The four remaining Knossos frescoes (II.2, II.15, and Alighting Leaper 2 and 3, see below) all come from the Court of the Stone Spout, and may have formed, together with other fragments found there, a sequence of bull-leaping scenes. ${ }^{1.5}$ The concentration of frescoes with bullleaping scenes in the Court of the Stone Spout is striking, and suggests that the court served some function connected with the sport. Bull-leaping needs a larger space than the intimate Court of the Stone Spout, but it may have served for practice space or the athletes' Green-Room.

\section{CAtalogue}

\section{A. Front Assistants}

II.I. Sealing from Knossos, impressed by a ring or amygdaloid seal. LM IIIA:I.

Betts, BSA 62 ( 1967) 44, no. 63 (HM Iоor).

Bull stands right; in front, a figure stands facing it.

II.2. Wall fresco from Knossos, Court of the Stone Spout.

$K F A 4^{\circ}$, pl. XIIa.

Woman at left holds the horn (?) of a bull left. ${ }^{16}$

II.3. Sealing from Pylos Palace, impressed by a ring. LH IIIB:2-C.

CMS I 305.

Bull left in flying gallop; in front, a figure stands facing it with arms stretched out. Below, a dado of bosses connected by S-spirals.

other male figure (KFA pl. X.I-3, 5).

${ }_{16}$ Evans describes a wall relief fresco as a man holding the horn of a bull ( $P M$ III $504-507$, fig. $350 \mathrm{~A}$ ). According to the late Dr. Bernd Kaiser (personal conversation, May 1974) the object is not a horn, however, for it does not taper. It seems best, therefore, to omit this representation from discussion. 


\section{B. The Approach}

II.4. Wall fresco from Knossos, the North-West Treasury. KFA 38, pl. VIII.2. Bull left in flying gallop; in front, a large plant. Preserved at the top are several (three ?) strands of hair (leaper's ?) probably near the missing bull's head. A reconstruction of the fresco is difficult, but possibly the leaper dives above the bull's head, his locks flowing below him.

II.5. Stone pyxis fragment from the Acropolis of Athens (NM 7249).

JdI 7 ( 1892 ) figured on p. 80. ${ }^{17}$

Bull left; above its head, a leaper floats looking down toward the bull's neck.

II.6. (pl. 21, figs. 4-5) Cushion-shaped seal of agate, bought in Izmir and said to be from Priene.

CS k. 202; Boardman, Greek Gems and Finger Rings b/w pl. 58, color pl. 49.5.

Bull stands left with front legs raised up on a cubical structure decorated with zigzags, and with its head lowered partway into the box. Above, a leaper right dives head first onto the bull's neck.

C. Diving Position I

II.7. Sealing from Knossos, Room of the Niche, impressed by a ring or amygdaloid and then counter-marked. LM IIIA:I.

KSPI p. 73, no. $\mathrm{O}_{4}$ (HM ro8); Betts, fig. I Ib.

Bull right in a flying gallop; above, a leaper, arms outstretched before him, descends to the bull's back.

II.8. Sealings (two) impressed by a single ring or amygdaloid. LM Ib. ${ }^{18}$

Kato Zakro-Hogarth, JHS 22 (I902), 86 no. 96, fig. 27 , pl. IX (HM I2); Betts, fig. 4 b; Sakellariou I.ro.

Sklavokampos-Marinatos, EphArch 1939I94 I, pp. 89-9o, no. 5, pl. 4.5 (HM 625); Betts, fig. 4a; Sakellariou I.I6.

Bull right in a flying gallop; above, an obviously male figure descends over the bull's neck with hands stretched down before him.

II.9. Sealing from Ayia Triada, impressed by a ring or amygdaloid. LM Ib. ${ }^{19}$

Levi, $A T$ i2 r, no. i 1o, fig. I26, pl. XI (HM 516); Betts, fig. Ira; Sakellariou II.r3.

Bull right in a flying gallop; above, a leaper, arms outstretched before him, descends to the bull's back.

${ }^{17}$ Dr. John Sakellarakis will publish a full study of this important piece soon.

18 Betts, $17-18$, attributes these sealings to a single signet.

19 Betts, I8 fig. IIa, relates this sealing to II.8, but he observes that this sealing is larger. The destruction fire, however, may have expanded the clay.
II.ro. (pl. 20, fig. 6) Lentoid of agate (Nauplia Museum ex no. 69.8I3) from Mycenae, House with the Idols. LH IIIB:2.

Unpublished. ${ }^{20}$

Two bulls stand right, the far bull regardant; above the far bull, a male leaper, curved around the bull's head and touching its muzzle for support, descends to the back; at right, a tree.

II.II. Wall fresco from Mycenae. ${ }^{21}$

Rodenwaldt, AthMit $3^{6}$ (r9I I) 230, pl. IX. Bull to left (?); above the withers, a man's hand, fingers to right.

II.r2. Ivory figures from Knossos, the Service Stairs near the Temple Repositories. MM III? $P M$ III 428-35, figs. 294-300, supp. pl. XXXVIII

The almost complete leaper (PM III fig. 296) stretches forth his arms probably towards the bull's withers (cf. PM III fig. 302, a bull's head in faience found in the same deposit). Remains of at least four other leapers are extant.

\section{Diving Position 2}

II.I3. Lentoid of chalcedony from Knossos. CM k. 357, pls. XI and XXVIII; Sakellariou I.r9. (HM 3209.)

A bull right, head thrown up; above, a leaper, arched so that his left leg appears on the near side of the bull's flanks.

II.r4. Sealing from Knossos, the Landing of the Grand Staircase, impressed by a ring or amygdaloid. LM IIIA: $x$.

KSPI p. 79, no. R8 (HM ro8); Betts, pp. 26-27, fig. I Ic.

A bull right in a flying gallop, head tucked down; above, a leaper.

II.15. Wall fresco (the Taureador Fresco) from Knossos, the Court of the Stone Spout. KFA 38-39, pl. IX.

Bull left in a flying gallop. A female front assistant holds the horns with her hands. A male leaper executes a back flip above. Behind the bull stands a female rear assistant with both arms stretched out toward the leaper.

II.I6. Lentoid of haematite from Crete.

CMS VII ro8; Sakellariou I.r8.

A bull right, head en face. Above, a leaper, whose left leg appears on the near side of the bull's flanks. The athlete supports himself by a hand on the bull's horns (cf. III.I below).

II.I7. (pl. 21, figs. 7-8) Gold ring (the bronze lower half of the bezel originally carried the

$20 \mathrm{I}$ am grateful to Lord Wm. Taylour for his kind permission to include this seal.

21 Lamb, BSA 24 (1919-1921) 193, suggests that this piece and his fresco fragments, nos. 4-6, from the Ramp House may belong together. Though two of his fragments depict bulls (nos. 4 and 5), none shows a leaper. 
lower half of the design) from Asine Tomb I. LH IIIA:2.2 ${ }^{22}$

CMS I 200; Sakellariou I.2I.

A bull right in a flying gallop. Above, a leaper; his hands, placed on the bull's neck and back, support him (cf. III.4 below).

II.r8. (pl. 21, figs. 9-10) Lentoid of lapis lacedaemonius from Gythion. ${ }^{23}$

CS k. 209.

A bull left in a flying gallop, a dog or lion runs below to right and nips the hind legs. Above, a leaper.

II.I9. (pl. 2I, figs. II-I2) Lentoid of onyx with a back once conical but later cut down (?), from the Peloponnese.

CS k. 246.

Two bulls in flying gallop counterclockwise, hooves to the rim. Above one is a leaper, in front of the other stands an assistant.

II.20. Plate seal of agate from Thebes, the Treasure deposit. LH IIIB:r.

ILN 28 November 1964, p. 860 (Arch. Section 2207) fig. 4.

A bull right in a flying gallop, head stretched up and forward; above, a leaper whose head appears on the near side of the bull's flank.

E. Diving Position $2 \mathrm{I} / 2^{24}$

II.2I. (pl. 20, figs. 13-I4) Amygdaloid seal of carnelian with gold caps, from Mycenae T. 5r8. LH I-II.

CMS I 152; Sakellariou I.20.

A bull left in a flying gallop, head tucked down; above, a leaper, his body now broken away, is partially masked by a gold cap.

II.22. (pl. 22, fig. 15) Sealing impressed by a ring and then countermarked, from the Pylos Palace. LH IIIB:2-C.

CMS I 370.

A bull left in a flying gallop above a dado of bosses; above, a leaper.

\section{ALIGHTING LEAPERS}

Five representations depict leapers alighting, the bulls usually running left. The leaper faces away from the bull, his arm thrown out behind him for balance or else tucked in at the chest (AL.5). These alighting leapers can belong either to Evans's Sche-

\footnotetext{
22 The author examined this ring and its apparent twin (CMS I 20I) to determine if the latter could have also carried a bull-leaping scene: it is not impossible. Although the two rings are physically different (CMS I $20 \mathrm{I}$ is smaller, its gold is impure, and the bronze is recessed for a plate which would have carried the top half of the design), the lower position of the bull on CMS I 201 would leave ample space for a leaper above. The object before the bull is surely the trunk of a tree, while that below could be the crudely executed tip of the animal's tail.

${ }^{23}$ It is possible that the origin given was suggested by the
}

ma or to that of the Diving Leaper; they therefore receive their own rubrics.

All the representations come from known contexts; four from Crete and one from Pylos. None seems to be dated later than LM IIIA:I: the sealtype AL.4 is known on sealings from LM Ib deposits at Ayia Triada, Sklavokampos and Gournia; the fresco AL.5 from Pylos appear stylistically close to the Minoan frescoes and therefore is probably LH I-II; ${ }^{25}$ and the examples AL.I-AL.3 are probably no later than LM IIIA:I.

Since these alighting leapers are to be dated no later than LM IIIA:I and most come from Crete, inclusion in either Evans's Schema or the Diving Leaper Schema does not seriously alter the conclusions reached concerning the date and provenience of either type.

\section{CATALOGUE}

AL.r. Sealing impressed by a lentoid (?), from Knossos. LM IIIA: I.

Betts, BSA 62 (1967) 32, no. io (HM I033).

A bull right; in back of the bull, a figure alights left (?), his left arm raised. ${ }^{26}$

AL.2. Wall fresco from Knossos, the Court of the Stone Spout.

$K F A$ I7, pl. Ar; Sakellariou I.2.

At lower left, the hind legs of a bull left in a flying gallop; a male leaper, to right, alights, his right arm thrown behind him.

AL.3. Wall fresco from Knossos, the Court of the Stone Spout.

KFA I7, pl. $\mathrm{A}_{2}, \mathrm{X}_{4}$.

The fresco fragment preserves no bull; it presumably runs left. A male leaper has just alighted; he faces right, his right arm thrown back.

AL.4. (pl. 21, fig. I6) Sealings (six) impressed by a single ring. $\mathrm{LM} \mathrm{Ib.}^{27}$

Ayia Triada-Levi, $A T$ ror, no. 54, fig. 75 , pl. XIV (HM 497-99); Betts, fig. 2b; Sakellariou I.r.2.

Sklavokampos-Marinatos, EphArch 1939I94I, p. 88, no. 2 (HM 628 and 629); Betts, fig. 3 .

stone. Cf. note 3 I below.

${ }^{24} \mathrm{~A}$ gold ring, said to be from Archanes (PM III 220 fig. 154) and now in the St. Louis Art Museum (Bulletin of the City Art Museum of St. Lonis 32 [1947] 99-103), also depicts a leaper in this position over a bull running right in a flying gallop; it is a well-known forgery.

25 Pylos II 50.

26 The incomplete preservation leaves its reconstruction uncertain; this leaper could, of course, be a rear assistant (cf. II.I5).

${ }^{27}$ Betts, $16-17$, attributes these sealings to one signet. 
Gournia-Gournia 54, fig. 30.4 (HM IоI); Betts, figs. ra and $2 a$.

A bull left in a flying gallop; in back of the bull, a leaper alights right, one arm stretched behind him.

AL.5. Wall fresco from Pylos Palace.

Pylos II p. 77 , no. $36 \mathrm{H}$ i05, pls. 24, I 6 , I 24 , and $\mathrm{C}$.

At lower left, the hind legs of a bull left in flying gallop; at right, a male leaper alights right, arms tucked against the chest.

\section{THE SCHEMA OF THE FLOATING LEAPER}

Seventeen representations of bull-leaping depict the bull-leaper in one static, though pleasing, pose above the bull. ${ }^{28}$ The leaper seems to float there horizontally with legs bent, his head toward the bull's. Usually the leaper grasps the horns or neck of the animal presumably using them as supports or pivots. Mrs. Sakellariou first isolated this pose from Evans's Schema in her Group II; she catalogues eleven examples. ${ }^{29}$

Since the leaper is consistently depicted as if frozen in this position, it is difficult to reconstruct the total sequence of the leap. If these representations do reflect an actual method, it is possible that the leaper came at the bull from the one side and vaulted over to the other instead of approaching the bull from the front.

On the other hand, the position of the leaper may be due to aesthetic rather than to gymnastic considerations. Of the seventeen clear examples of this pose (III.I-I7) eleven appear on lentoid seals, and two (?) on sealings impressed by lentoids; of the remaining examples one appears on an amygdaloid seal from Mycenae (III.13), one on a fresco from Tiryns (III.I), one on a larnax from Tanagra (III.2), and one on a sherd from Mycenae (III.I4). Thirteen of these seventeen representations are thus contained by the tondo form of the lentoid. The body of the leaper conveniently fills the small space above the bull's back; the angular pose contrasts

\footnotetext{
28 CMS IV 289, a steatite lentoid from the Messara in Crete, may once have carried a bull-leaping scene of Type III, but it is too worn to warrant inclusion. There is also a lentoid set in a ring now in a private collection in Larissa ( $A A$ 1959, I06, fig. 25). The seal is said to have been long in the Giannopoulos family. The pose of the leaper is right for Type III but the bull is wrong; so too, probably, is the exergue with half-rosettes. The author has doubts about this seal's antiquity and prefers to leave it out of discussion.

29 The author has no more information on HM 33 than Mrs. Sakellariou (her Group II.4); it is not on display in the Heracleion Museum. Therefore, the seal is not included in the catalogue of Type III. A fourth seal in the Ashmolean Museum illustrating this schema (her Group II.II) is not published in
}

with the curve of the lentoid's field and denies the direction and movement apparent in the two previous schemata. This static and rigid quality, apparent in almost all Type III representations, would seem then to be a desired aesthetic trait.

Whereas frescoes may have inspired the Type I and II representations on sealstones, it is quite likely that seals provided the model for the Tiryns fresco, the Tanagra larnax, and the Mycenae sherd. Like most of the seals of this group, these three representations concentrate attention on the static composition. $^{30}$ Such stark presentations are likely to have originated from a design intended for the cramped field of a sealstone. The opportunities for narrative expansion and embellishment inherent in the fresco form are generally ignored; an assistant, a plant, and a naturalistic setting appear only once each (III.3, III.4, and III.I2 respectively). In almost all the representations in Type III, the actual drama of the sport, the skill of the leaper or the power of the bull, is scarcely hinted at. The sport seems forgotten and consequently the composition becomes a jumping-off point for fanciful variations: the Master of Animals added on the Tanagra larnax (III.2), the ruminating bull in his paddock (III.r2), the goat as bull-surrogate (III.I5).

Eleven representations of this third schema have known origins. Four come from Crete (III.7 from the Little Palace at Knossos, III.8 from Gournes, III.9 and III.I2 from East Crete). Seven are from the Mainland (III.I from Tiryns, III.2 from Tanagra, III.5 from Dimini, III.I 3 and III.I4 from Mycenae, III.I5 from Akonas, and III.I 7 from Pylos). Since two other representations are carved on lentoids of lapis lacedaemonius, ${ }^{31}$ these last may also be from the Mainland, though one seal of lapis lacedaemonius (III.8) was found at Gournes in Crete.

Secure dates can be assigned to four examples: III.2 from Tanagra and III.I7 from Pylos (LH III

CS; it also is not included in this catalogue.

30 The Tanagra larnax adds an unlikely assistant to hold the two bulls; both the superhuman effort of this feat and his pose makes him a probable Master of Animals. In addition, the larnax adds a third, uncomplicated representation of this schema.

$31 \mathrm{On}$ the lapis lacedaemonius quarries east of Gythion: Waterhouse and Simpson, "Prehistoric Laconia: Part I," $B S A$ 55 (1960) especially 105-107. To find the quarries it is easier to begin from the village of Stephania west of Skala and south of Krokeai. Pass through the village and continue north on the earth road. After a kilometer, the visitor will note deep depressions in the earth to either side of the road. The large stones of lapis lacedaemonius lie loose in the earth and need only prodding to remove them. 
B:2-C:I), III.8 from Gournes (LM IIIB:I) and III.I4 from Mycenae (LH IIIB). The fresco from Tiryns appears stylistically later (LH III?) than the LB I-II frescoes from Knossos and Pylos (II.I5 and AL.5). ${ }^{32}$

Though these statistical data are limited, we may state tentatively that the Type III schema was mostly restricted to lentoid seals, that it found slightly greater favor on the Mainland than in Crete, and that it had a floruit in LB IIIB.

The only objection to a IIIB date for the Floating Leaper Schema is presented by III.7, described by Evans as a sealing from the Little Palace. As far as is known there is no evidence for a LM IIIB conflagration in the Little Palace which could have fired the sealing, nor is the evidence for a LM IIIB bureaucracy, necessary for the production of the sealing, compelling. The sealing is not extant, and it is therefore impossible to check it against the accuracy of Evans's sketch in his notebook ( $K S P I$ pl. I7 $\mathrm{U}_{5}$ ); it is possible of course that Evans's sketch is inaccurate and that the actual scene was quite different. Other inaccuracies in his notebooks also suggest the possibility that the sketch does not reflect a sealing, but a seal, and even that such a sealing or seal was found elsewhere. ${ }^{33}$ It seems best to suspend judgment until the sealing surfaces.

Recently, Miss A. Tamvaki grouped four of the lentoid seals in this schema to form a common workshop: III.8, 9, I0, and II. ${ }^{34}$ She also placed twelve more seals close to this workshop (among which are II.I6, III.3, and III.6). All these seals show an extensive use of the drill for joints, eyes, and other parts of anatomy; their compositions contain other schematic features, notably the linear quality both of the human hand and feet, and of the bull's legs and horns. Although a detailed study of workshops lies outside the scope of this paper, it may be noted that the similarities in pose, style, and medium suggest that Type III was the creation of a circle of closely allied masters who may have been working in LB IIIB.

\section{CATALOGUE}

\section{A. Bull with head in profile}

III.r. Wall fresco from Tiryns (NM I595).

32 Pylos II 77.

33 When Evans used his notebooks to produce PM, many understandable errors crept in; several are well known. For our purposes compare a seal from Zafer Papoura T. 36 (CS k. 7 P: Archaeologia 59, pt. 2 [1905] 448 fig. 6I) which is described as a sealing from the Domestic Quarter (PM III 3 I 7 fig. 209:
Schliemann, Tiryns (German ed.) 34550, pl. 13; (English ed.) 303-307, pl. 13; Rodenwaldt, Tiryns II I62-65, pl. I8; Sakellariou II.I.

A bull left in a flying gallop; above, a leaper.

III.2. Painted larnax from Tanagra T.22 (LH IIIB end-C:I), lower register on one long side.

$A A A_{3}$ (1970) i 84-97, fig. I6.

Two bulls stand face to face in axial symmetry, a leaper above each grasps a horn with one hand and the shoulders with the other; between the two bulls stands a figure holding their horns in a position resembling that of a Master of Animals. At the right, a third bull walks to right with a leaper above in a similar position to that of the others.

III.3. (pl. 20, fig. I7) Lentoid of haematite, unknown provenience.

CMS VII rog; Sakellariou II.7.

A bull stands or steps left; leaper above. A front assistant stands before the bull and holds either the horns or the right hand of the leaper.

III.4. Lentoid of carnelian, unknown provenience. Antike Gemmen in deutschen Sammlungen vol. I Munich 45.

A bull runs right; in front of it, a plant; above it, a leaper who grasps a horn in his left (?) hand.

B. Bull with head thrown up

III.5. Lentoid of marble from the Dimini tholos. CMS I 408.

A bull right; above, a leaper whose right hand appears touching or resting on the bull's flank.

III.6. Lentoid of lapis lacedaemonius, unknown provenience.

CS k. 248.

A bull runs left; above, a leaper.

C. Bull en face

III.7. Sealing impressed by a lentoid (?) from Knossos, the Little Palace.

KSPI p. 88, no. U5, pl. I7.

A bull runs (?) left; above, a leaper whose right (?) hand grasps the bull's left horn.

III.8. (pl. 22, figs. I8-19) Lentoid of lapis lacedaemonius with a conical reverse from Gournes, Crete, Tomb I, within the larnax. (HM I232) LM IIIB: I.

KSPI C55); and a seal found near the Court of the Stone Spout (BSA 8 [I90I-I902] I02 fig. 59) described as a sealing from the Domestic Quarter (PM IV 344 fig. 287a).

34 "A Late Minoan Seal in the N. Metaxas Collection," AAA 6 (I073) 308-I5. 
Deltion 4 (1918) 66, pl. 5.I; Furumark, Chronology io5; Sakellariou II.3.

A bull runs right, leaper above.

III.9. Lentoid of green steatite from Aimonas Livadia, Crete. (HM I 385 Metaxas Coll.)

$A A A 6$ (1973) 308-15, fig. I.

A bull runs left; above, a leaper whose right hand grasps (?) the bull's left horn.

III. Io. Lentoid of lapis lacedaemonius with a conoid reverse, of unknown provenience.

CS k. 34I; Boardman, Greek Gems and Finger Rings pl. 124.

A bull runs right; in front a figure-eight shield, and above, a leaper.

III.II. Lentoid of haematite, worn, of unknown provenience.

CMS VII 257.

A bull runs left, leaper above.

D. Other representations

III.r2. (pl. 22, figs. 20-2I) Lentoid of burnt banded agate from Praisos, the bath adjoining Tomb D. (HM 185)

$B S A 8$ (190I-1902) 252, 254, fig. 25; Boardman, Greek Gems and Finger Rings pl. 92.

A bull couchant right; above, a leaper grasps both horns. Horizontal lines and a frond provide a pasture, while other lines fill the upper space.

III.r3. Elliptical amygdaloid of carnelian from Mycenae T.44.

CMS I 79; Sakellariou II.5.

A bull stands or walks right; above, a leaper supports himself by one hand at the bull's neck.

III.I4. (pl. 20, fig. 22) Body sherd of a Deep Bowl or Krater from Mycenae. (NM 2675) LH IIIB. ${ }^{35}$

JdI VII (1892) 72-8I; Furumark, MycPottery 438.

A bull to right. Above, a leaper supine; his left leg, however, prepares for the landing.

III.15. Lentoid of chalcedony from Akonas Tholos I near Pylos. (Pylos Museum I45)

Deltion is Khronika I964, 163-64, pl. I64c.

A goat (agrimi) runs or rears left; above, a leaper clasps the agrimi's withers to steady himself.

III.I6. (pl. 21, fig. 23) Lentoid of onyx with a conical reverse, of unknown provenience.

CS k. 249; Boardman, Greek Gems and Finger Rings pl. ro3.

35 I am grateful to Dr. John Sakellarakis for his permission to study this sherd and to include it here.

L. $8.0 \mathrm{~cm}$. H. $4.6 \mathrm{~cm}$., Th. $0.5 \mathrm{~cm}$., est. D. of bowl $17.5 \mathrm{~cm}$.

The sherd, of buff fabric, is not painted on the inside.

36 Compare the sealing impressed by a ring from Knossos, the Landing on the Grand Staircase (HM 25I; LM IIIA:I) -
A bull right in a flying gallop. Above, a leaper; below, a figure lies (?) horizontal. ${ }^{36}$

III.I7. Sealing from Pylos Palace impressed by a lentoid (?). LH IIIB:2-C:I.

CMS I 378.

Bull runs (?) right, a leaper above.

IV. MISCELLANEOUS

Three representations depict poses which are difficult to reconcile with the three previous types.

They had best form a separate section.

A fresco from Knossos (IV.I) shows a prone female leaper and two apparently wavy black lines before her; the fresco was restored (PM III fig. I43) as depicting two tandem leapers. If the two black lines do not depict the wavy locks of a second leaper they may be the traces of the bull's horns (cf. III.I) or some other detail of the scene (cf. the foliage on II.4). ${ }^{37}$ The pose of the female leaper shares some resemblance with that of the Floating Leaper.

On a sealing from Sklavokampos (IV.2, LM Ib) a leaper appears to pivot on the bull's head so as to land on its back facing the horns. The pose of the leaper on a lentoid from Mycenae (IV.3) suggests that he also pivots on the bull's head and then alights on the ground at its side. Both representations seem to depend on some kind of vaulting where the bull's head is used as a pivot point; they may thus be related to Type III.

\section{CATALOGUE}

IV.I. Wall fresco from Knossos, the Queen's Megaron.

PM III 208-209, fig. I43; Bulle, Orchomenos I I 28 , fig. 38 .

Traces of a bull's neck to right. Above, a female leaper, her arms outstretched before her towards two wavy (?) black lines.

IV.2. Sealings (fifteen) impressed by a ring, from Sklavokampos. LM Ib.

Marinatos, EphArch I939-I941, 88-89, no. 4, fig. I5, pl. 4.4 (HM 613); Sakellariou I. 5 .

A bull right en face in a flying gallop. Above, a leaper descends to the bull's back, his right leg outstretched, his hands still retaining their

KSPI 79, no. R9, pl. I3. Also compare CMS I i7 I from Mycenae. 37 Bulle identifies two prone figures on an Orchomenos fresco as leapers (Orchomenos I 79-90, pl. 28.8) on the basis of the restored Knossos fresco. Since no bull is preserved and the restoration of the Knossos fresco is problematic, the Orchomenos fresco is omitted from discussion. 
hold on the pivot between the bull's horns. Below, a dado of running spirals.

IV.3. (pl. 22, fig. 24) Lentoid of onyx from Mycenae T. 47 .

CMS I 82; Sakellariou II.6.

A bull runs right; above, a leaper swings off the bull's shoulders. He supports himself by one hand on the horn, by the other on the neck (cf. II.ry). Below, a tree or large plant lies horizontal (cf. III.r6).

\section{CONCLUSION}

The evidence presented above suggests that there were three main systems of depicting bull-leaping. Evans's Schema is poorly documented but its representations appear to be entirely Minoan and do not survive the destruction of Knossos. The Diving Leaper Schema, however, is richly illustrated both in Crete until LM IIIA:I and on the Mainland almost throughout the Late Helladic period. The Floating Leaper Schema also consists of numerous examples, slightly more than half coming from the Mainland. From the four examples which derive from dated contexts it seems plausible to suggest a LB IIIB floruit for the schema, a date which agrees well with its formal and mannered style.

Only the Floating Leaper Schema presents no evidence for an actual bull-leaping sequence. Instead, all representations depict the same pose. It is probable, therefore, that the intention of this schema was entirely artistic and that its creators were not depicting an actual method of bull-leaping. The representations of Evans's Schema and of the Diving Leaper Schema, on the other hand, do seem to have been based on the maneuvers of actual bullleaping systems.

Evans's Schema, requiring a dashing bull and a thrilling snap over the back from the horns, is dramatic and dangerous. But it does not seem practicable. Evans's leaper must be certain that after he has grasped the bull's horns the animal will throw its head directly back. This seems doubtful, even allowing for trainable Ferdinands; surely the bull shakes an object from his horns by throwing his head to the side. It is also difficult to imagine that a leaper would be able to execute both his somersault and his touchdown on the bull's hindquarters if the bull moves rapidly forward out from under him.

The unique bronze group in the British $\mathrm{Mu}$ seum is crucial for the acceptance of Evans's Schema. This group presents problems, however, for the rendering is stiff and the peculiar attachment of the leaper to the bull seems to arise more from the technical problems of creating a single group than from a desire to reflect an actual maneuver. A less complicated sculpture is represented by the silver bull carried by a Keftiu tribute-bearer on a fresco in the tomb of User-Amon (PM II 736 fig. $47 \mathrm{I})$. This bull appears in a flying gallop but without its leaper.

If the bronze group is excluded on the grounds that the pose of the leaper grew out of technical considerations then it is possible that the schema described by Evans depends primarily on aesthetic considerations.

The Diving Leaper Schema, however, corresponds well to the difficulty and danger of the sport. Approaching the bull from above or diving over a bull with its head lowered (cf. II.I4, II.2I, and also I.5) lessens the danger of the leaper's being gored; a flip from the withers does not require the bull to stay in place but can be executed even while the animal is charging if the leaper's dive is aimed low enough; the various front assistants witness the need to secure the bull; and the box on the Priene seal must represent an actual prop, for it is unlikely to be purely the product of an artistic imagination.

It seems likely therefore that of the three schemata presented, only that of the Diving Leaper reflects bull-leaping maneuvers at all accurately. This is not to say that the Diving Leaper Schema is not also influenced by aesthetic considerations; one need only look at the disproportionate size of the bull (undoubtedly symbolizing its power) to that of the human figures in the Taureador Fresco (II.I5).

In the Floating Leaper Schema, however, the artistic bias predominates, while the representations of Evans's Schema number too few to allow a full appreciation of its sequence.

A final word on chronology and the discontinuance of the sport. The latest representations of bull-leaping, according to the contexts are: III.8 from Gournes (LM IIIB:I); II.20 from Thebes (LH IIIB:I); II.Io from Mycenae (LH IIIB:2); III.I4 from Mycenae (LH IIIB); III.2 from Tanagra, and II.3, II.22, and III.I7 from Pylos (all LH IIIB:2-C:I ). If Type III, the Floating Leaper Schema, does not reflect the actual practice of bull-leaping, then the seals and sealings II.3, II.Io, II.20, and II.22, on the basis of their archaeological contexts, 
would seem to present the latest accurate depictions of the sport.

Of these four representations, II.3 and II.22, both from Pylos, appear stylistically early. The dadoes of spirals and bosses are comparable to those on several early Cretan sealtypes, ${ }^{38}$ while the sensitive modeling of the figures finds parallels on many of the early seals (compare, e.g. II.21 from MycenaeLH I-II context). It seems plausible, therefore, to regard the seals which impressed these two sealings as early, perhaps LH IIIA or earlier.

Seals II.Io from Mycenae and II.20 from Thebes come from LH IIIB contexts. Their styles seem to fit this date. The modeling on both is soft, the figures somewhat schematic, the bulls on II.ro elongated and elegant. The whole effect appears mannered and formal. But the actual maneuvers depicted on these seals are confused. The Theban bull-leaper is in an awkward position, with his head against the bull's flank, as if the artist placed it there for spatial reasons. The leaper's position, however, is not impossible, and it may reflect an actual event. The Mycenae bull-leaping scene (LH IIIB: 2), however, is more aesthetically based. The two bulls, both standing right, the far bull regardant, follow a standard pose for animal pairs observable on many seals (cf. the bulls on CMS I izo, CMS IV 256, and the goats on CMS I 74 and CMS VII 98); the bull-leaper must have been added in a fanciful moment, just as the variations in Type III were created in a similarly light vein.

${ }^{38}$ Cf. I. 4 and IV.2 (LM Ib contexts), the sealings from the LM IIb Royal Tomb at Isopata (Archacologia 59 pt. 2 [1905]
If, therefore, the Pylos sealings II.3 and II.22 (LH IIIB:2-C:I) were impressed by early signets, and the Mycenae seal II.Io (LH IIIB:2) contains too many aesthetic considerations to be a reliable depiction of bull-leaping, then it is possible that no representation dated to the close of the LB IIIB period reflects the feat accurately. The representations dated earlier, II.I7 from Asine (LH IIIA:2) and II.20 from Thebes (LH IIIB:I) do seem to record the sport more faithfully. Thus, on the basis of the representations, it is possible that bull-leaping was not practiced in LH IIIB:2, and, since the Theban seal II.20 seems to present an aesthetically altered scene, the sport may have been in decline even in the LH IIIB:I period.

In conclusion, bull-leaping begins to appear in artistic representations toward the beginning of the Late Bronze Age in Crete and on the Mainland. The main system of performance probably followed that of the Diving Leaper Schema. When bullleaping itself was discontinued, perhaps towards the close of the LB IIIA or at the beginning of the LB IIIB period, later representations depicted the leaper in the floating pose (Type III), a pose not copied directly from the sport.

\section{DUKE UNIVERSITY}

NOTE: CMS V, to be published this year, includes three of our sealstones, II.ro, II.20, and III.15, numbering them 597, 674, and 638 respectively.

fig. I38), and KSPI KI6 (PM I 694 fig. 516) probably no later than LM IIIA: $\mathrm{I}$.

\begin{tabular}{|c|c|}
\hline \multicolumn{2}{|l|}{ Frescoes } \\
\hline Knossos - KFA pl. Ar (Court of the Stone Spout) & AL.2 \\
\hline A2 (Court of the Stone Spout) & AL.3 \\
\hline VIII.2 (North-West Treasury) & II.4 \\
\hline IX (Taureador-Court of the Stone Spout) & II.I5 \\
\hline XIIa (Court of the Stone Spout) & II. 2 \\
\hline PM III fig. I43 (Queen's Megaron) & IV.I \\
\hline Mycenae & II.I I \\
\hline Pylos & AL.5 \\
\hline Tiryns & III.I \\
\hline Sealstones and Rings & \\
\hline Ashmolean Museum - CS k. 202 (Priene) & II.6 \\
\hline 209 (Gythion) & II. I 8 \\
\hline 246 (Peloponnese) & II. I9 \\
\hline 248 & III.6 \\
\hline 249 & III.16 \\
\hline $34 \mathrm{I}$ & III.10 \\
\hline
\end{tabular}


Athens National Museum - CMS I

79 (Mycenae)
82 (Mycenae)
I52 (Mycenae)
200 (Asine)
408 (Dimini)

British Museum - CMS VII Io8 (Crete)

II.I6

109

III. 3

257

III. I I

Heracleion Museum - 185 (Praisos)

III. 12

1232 (Gournes)

1385 (Aimonas Livadia)

III. 8

3209 (CM k. 357 - Knossos)

III.9

II. 3

Munich - Antike Gemmen in deutschen Sammlungen I 45

III.4

Nauplion ex. no. 69.8r 3 (Mycenae)

II.IO

Pylos Museum 145 (Akonas)

III.I 5

Thebes Museum (Thebes)

II. 20

Sealings

Ayia Triada - Levi $A T$ no. ${ }_{\mathbf{I}}^{54}$

Gournia - HM Ior I02

I.3

AL.4

I.3

Kato Zakro-Levi $K Z$ no. 96

II. 8

I.5

I. 4

I.7

Knossos-CMS I $5 \mathrm{I} 7$

KSPI $\mathrm{L}_{4} 8$

1.2

I.I

II. 7

$\mathrm{O}_{4}$
$\mathrm{R} 8$

II.I4

$\mathrm{U}_{5}$

III.7

Heracleion Museum roo I

II.I

I033

AL.I

$\begin{array}{rr}\text { Pylos-CMS I } & 305 \\ 370 \\ 378\end{array}$

II.3

II. 22

III.I 7

Sklavokampos - Heracleion Museum 6I2

613
625
628,629

I.3

IV.2

II. 8

AL.4

Miscellaneous

Athens Acropolis - stone pyxis

Knossos - ivory leapers

II. 5

Mycenae - pictorial sherd

Rethymnon (?) - bronze group

II. I 2

III.I4

I. 6

Tanagra - larnax

III. 2 

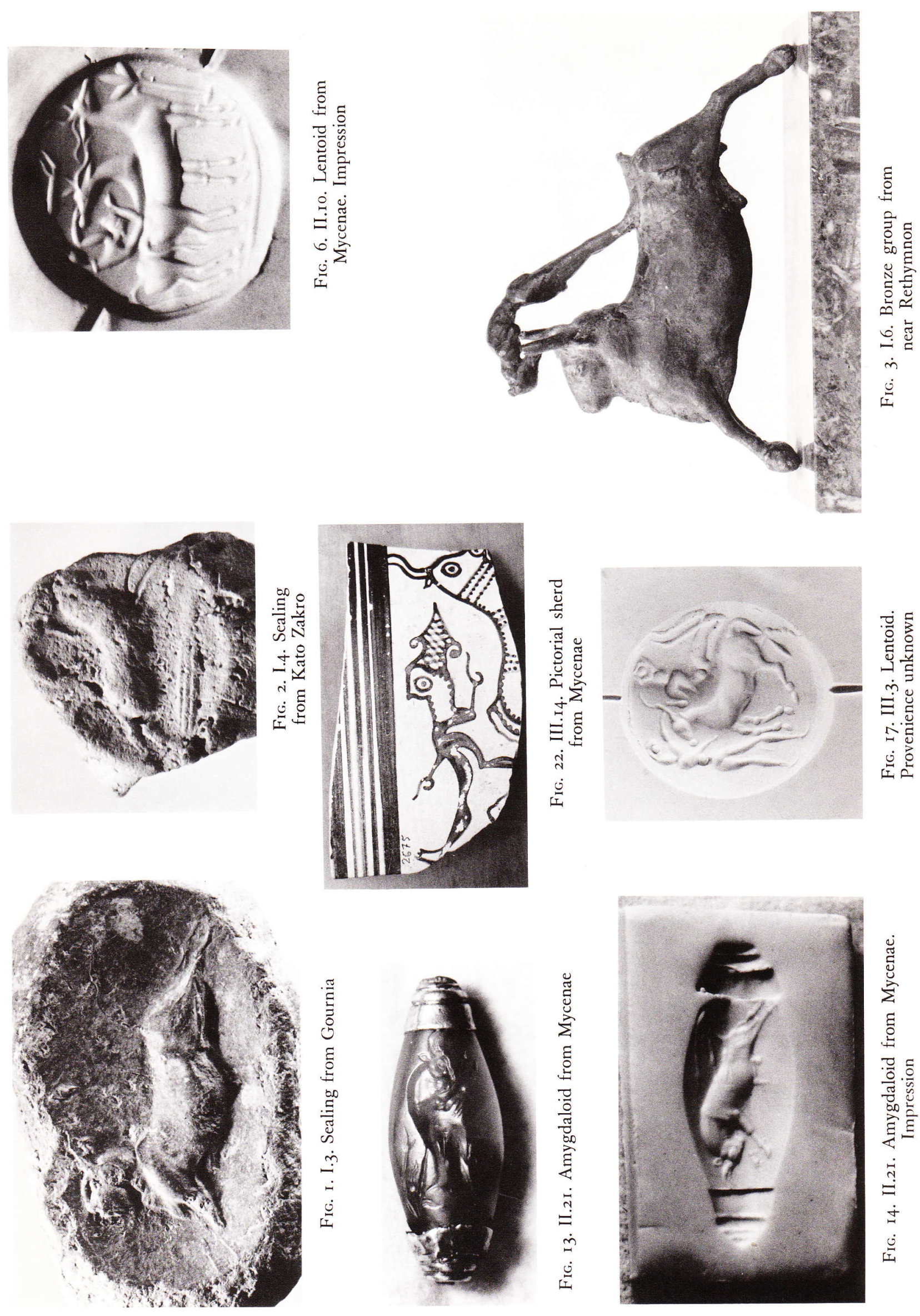

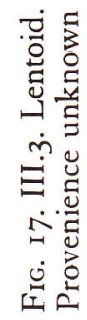

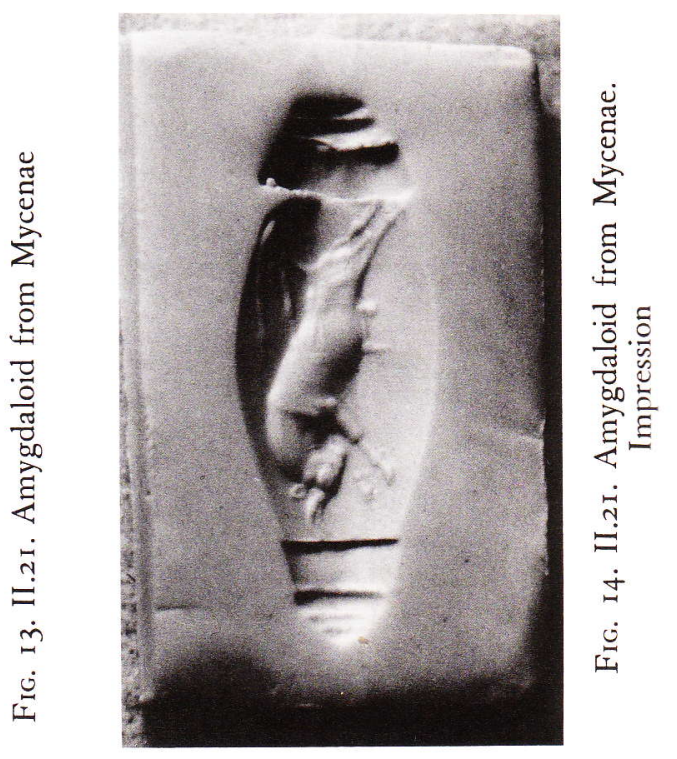




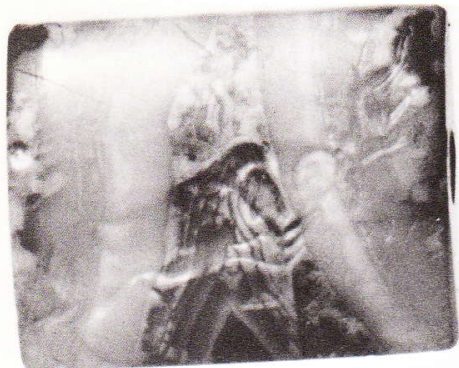

FIG. 4. II.6. Cushion-shaped seal from Priene

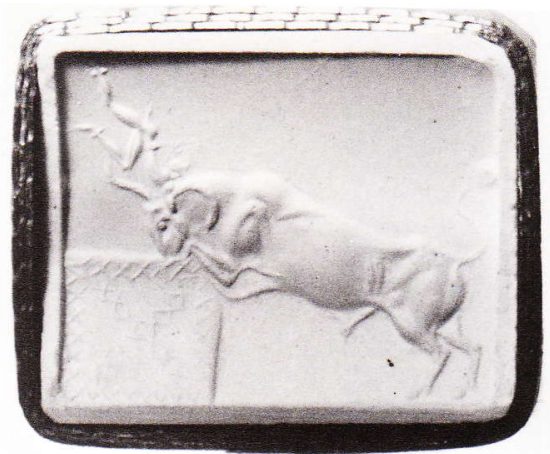

Fig. 5. II.6. Cushion-shaped seal from Priene. Impression

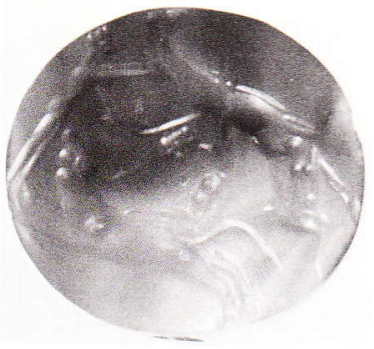

Fig. II. II. I9. Lentoid from the Peloponnese

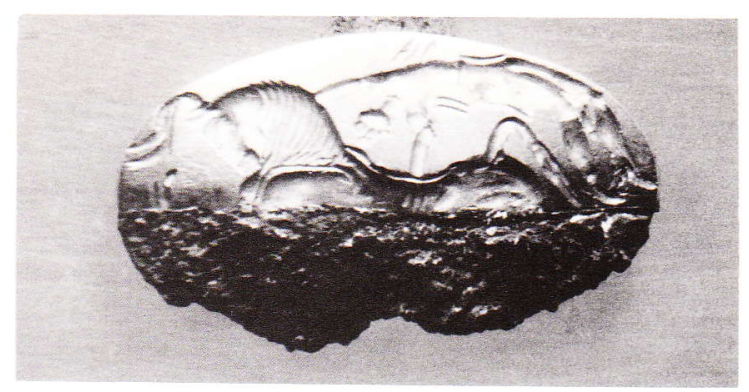

FIG. 7. II.I7. Gold ring from Asine

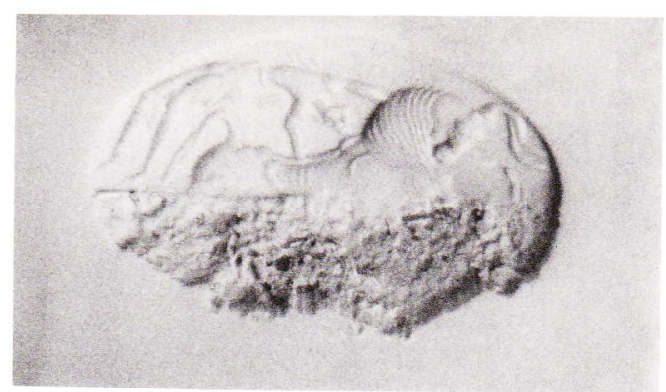

FIG. 8. II.I7. Gold ring from Asine. Impression

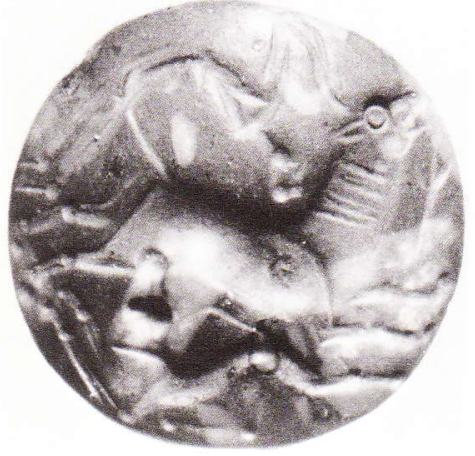

FIg. 9. II.18. Lentoid from Gythion

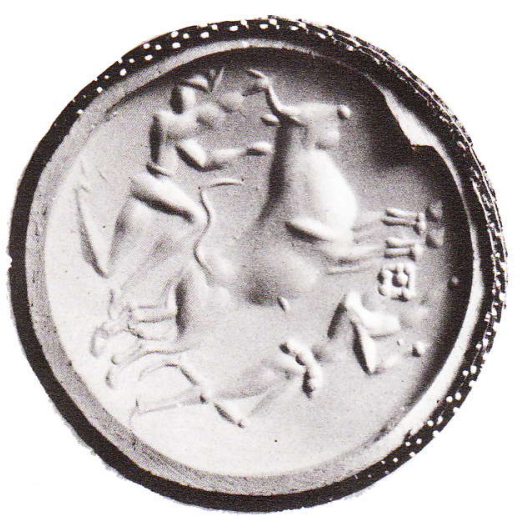

Fig. 23. III.I6. Lentoid.

Provenience unknown. Impression

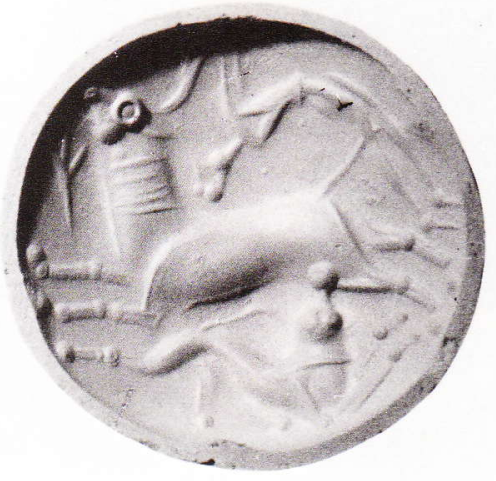

FIG. IO. II.I8. Lentoid from Gythion. Impression

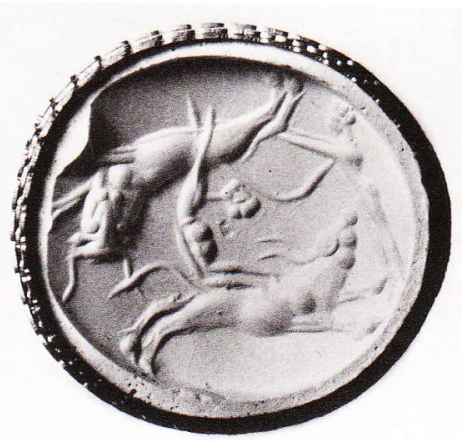

FIG. I2. II.19. Lentoid from the Peloponnese. Impression

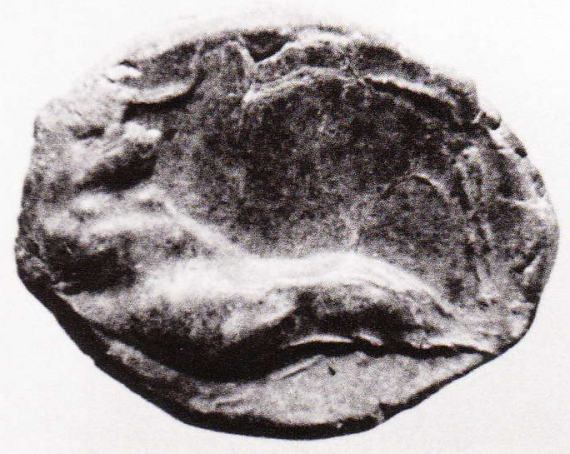

FIg. I6. AL.4. Sealing from Sklavokampos 


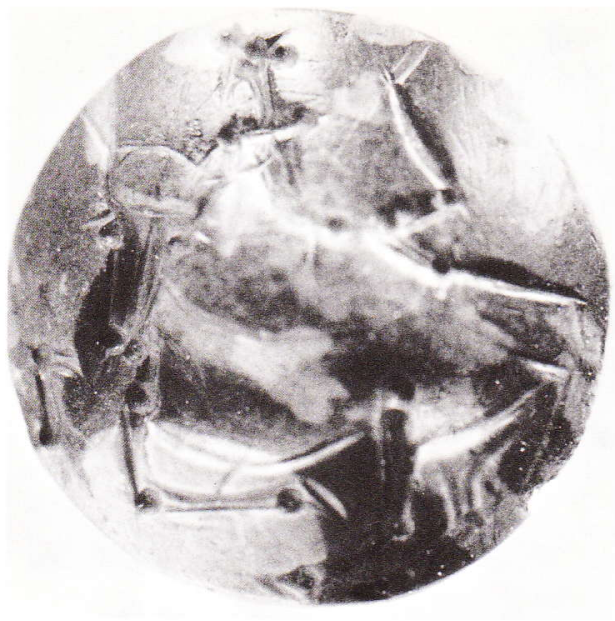

FIG. I8. III.8. Lentoid from Gournes

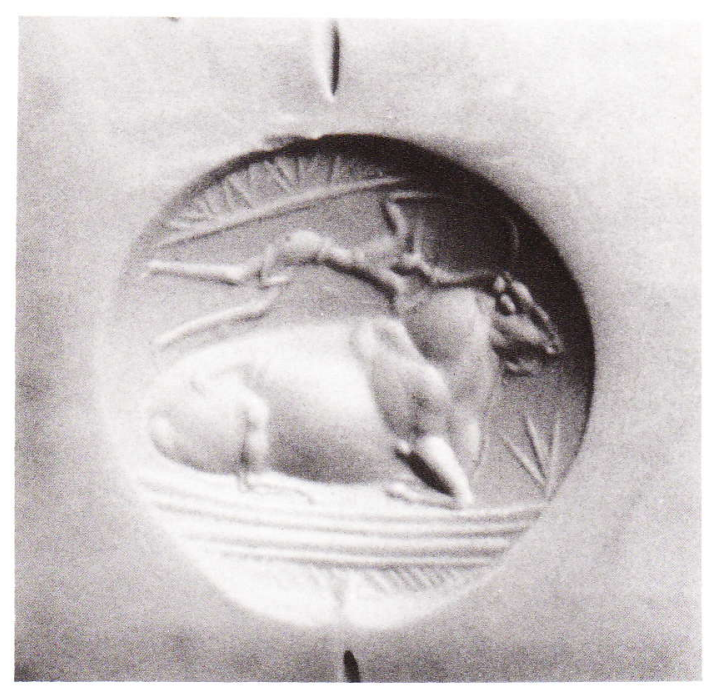

Fig. 21. III.I2. Lentoid from Praisos. Impression

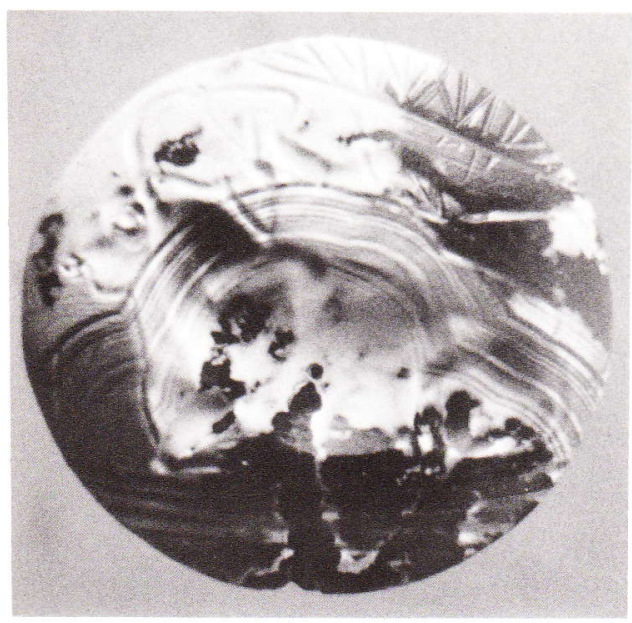

Fig. 20. III.I2. Lentoid from Praisos

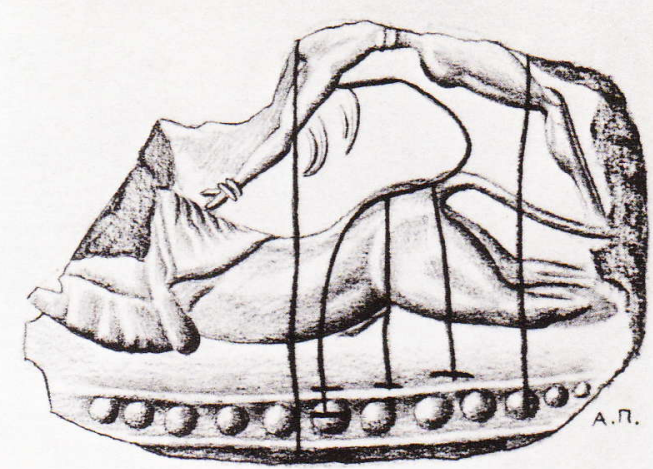

Fig. 15. II.22. Sealing from Pylos. Drawing

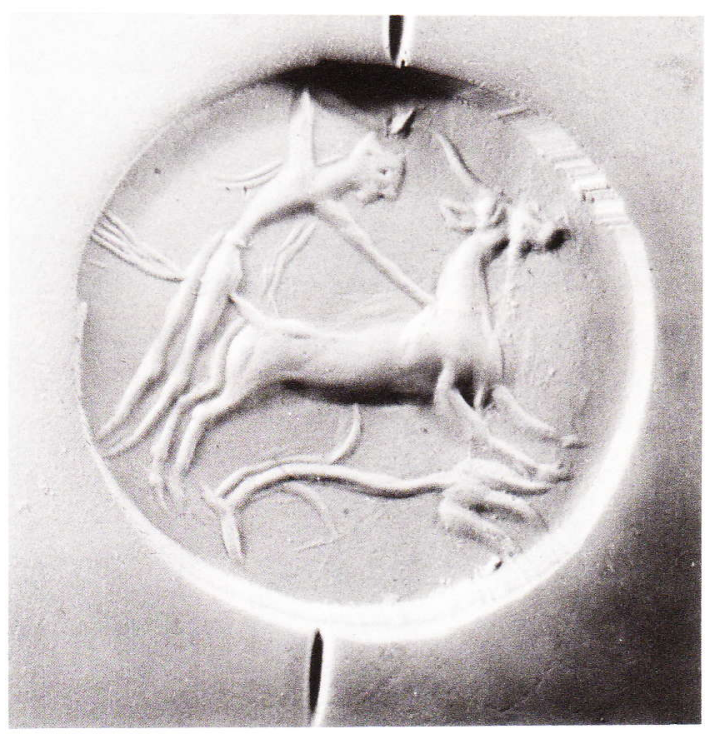

FIG. 24. IV.3. Lentoid from Mycenae. Impression

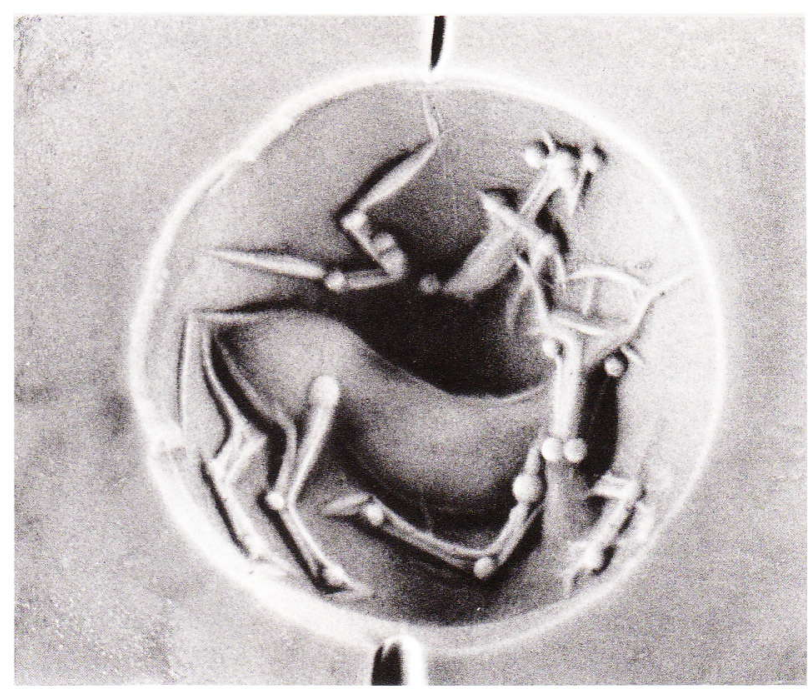

FIG. 19. III.8. Lentoid from Gournes. Impression 